IRA-International Journal of Management \& Social Sciences

ISSN 2455-2267; Vol.08, Issue 02 (August 2017)

Pg. no. 135-141

Institute of Research Advances

http://research-advances.org/index.php/RAJMSS

\title{
Supply Chain Management of Fruits: A Case Study on Marketing Channels of Mango in Bidar District, Karnataka
}

\author{
Gousoddin' ${ }^{1}$ Javed Miyan' ${ }^{2}$ Avanish Kumar ${ }^{3}$ \\ ${ }^{1}$ M.Tech - Food Technology (Food Chain Management), ${ }^{2}$ Msc - Agricultural Economics, ${ }^{3}$ Assistant Professor \\ Dept. of Food Process Engineering, VSAET, SHIATS, Allahabad - 211007, India.
}

Type of Review: Peer Reviewed.

DOI: http://dx.doi.org/10.21013/jmss.v8.n2.p1

\section{How to cite this paper:}

Gousoddin, Miyan, J., Kumar, A. (2017). Supply Chain Management of Fruits: A Case Study on Marketing Channels of Mango in Bidar District, Karnataka. IRA-International Journal of Management \& Social Sciences (ISSN 2455-2267), 8(2), 135-141. doi:http://dx.doi.org/10.21013/jmss.v8.n2.p1

(C) Institute of Research Advances.

\section{(cc) BY-No}

This work is licensed under a Creative Commons Attribution-Non Commercial 4.0 International License subject to proper citation to the publication source of the work.

Disclaimer: The scholarly papers as reviewed and published by the Institute of Research Advances (IRA) are the views and opinions of their respective authors and are not the views or opinions of the IRA. The IRA disclaims of any harm or loss caused due to the published content to any party.

Institute of Research Advances is an institutional publisher member of Publishers Inter Linking Association Inc. (PILA-CrossRef), USA. The institute is an institutional signatory to the Budapest Open Access Initiative, Hungary advocating the open access of scientific and scholarly knowledge. The Institute is a registered content provider under Open Access Initiative Protocol for Metadata Harvesting (OAI-PMH).

The journal is indexed \& included in WorldCat Discovery Service (USA), CrossRef Metadata Search (USA), WorldCat (USA), OCLC (USA), Open J-Gate (India), EZB (Germany) Scilit (Switzerland), Airiti (China), Bielefeld Academic Search Engine (BASE) of Bielefeld University, Germany, PKP Index of Simon Fraser University, Canada. 


\begin{abstract}
In the Era of stimulating growth, economic development and ever growing purchasing power of Indian consumer and induction of National horticulture mission by government of India as horticulture is significantly contributing to the Indian GDP and is planned to double the production of horticulture crops. What is required is the review, explore and channelize and have a good market structure essential for the success of the programs implemented by the government which are designed for uplift of population in whole. Indian market is dominated by unorganized retailing due to which there is heavy loss and escalation in the prices of commodities. This study is focused on determining the existence of different supply chains in the Bidar district of Karnataka involved in marketing of mangoes. The study is conducted by the structured questionnaires for the different intermediaries. It involve knowing the existing marketing chains in the district, Problem faced by the intermediaries involved in the marketing of mangoes and fruits in general and the value addition to the products, post-harvest facilities present in the district involvement of the $A P M C$ for fruit marketing and its reach and profit to the famers. There are no post-harvest facilities and separate APMC regulated fruit market, co-operative marketing facility is not there and involvement of intermediaries is escalating he price of the produce and producers share in consumer price is very less.
\end{abstract}

Key words: Bidar, Fruit Chain, Marketing, Supply Chain Management.

\title{
1 INTRODUCTION
}

The horticulture sector has in past few years, proved to be the engine of growth in agriculture for improving the productivity per unit area, source of generating employment, improving the economic well being of the farming community and the entrepreneurs involved in agriculture and horticulture and thereby enhancing exports and capable of earning considerable foreign exchange. India ranks first among world's mango producing countries accounting for about $46 \%$ of the global area and $40 \%$ of the global production. Special care is needed in development of horticultural sector due to inherent constraints like perishability. The markets of horticultural products in the country lack a systematic approach of supply management. Mostly growers realize a fraction of the price paid by the consumer. A sizeable fraction of the price is cornered by the functionaries/traders or lost in the long marketing chain. This is due to lack of availability of infrastructure. Moreover, all stake holders beginning from growers to consumers are not well integrated. The post harvest losses in case of horticultural crops range between 30-40 per cent. These are primarily due to inefficient handling, transportation and lack of storage. Thus, efficient cold storage and cold chain are essential which is grossly inadequate to meet the growing demand in future. The horticulture sector in India is characterized by small, segregated farms with low per-hectare yields and huge postharvest losses, owing to outdated practices (Usha and Subhash 2012).

The important mango producing states in India are Andhra Pradesh, Uttar Pradesh, Karnataka, Bihar, Gujarat, Maharashtra, Tamil Nadu, West Bengal, Kerala and Orissa (NHB).

Table 1.1 Production statistics of mango in India

\begin{tabular}{|c|c|c|c|}
\hline & \multicolumn{3}{|c|}{$\mathbf{2 0 1 3 - 1 4}$} \\
\hline STATE & $\begin{array}{c}\text { AREA } \\
000{ }^{\prime} \mathrm{HA}\end{array}$ & $\begin{array}{c}\text { PRODUCTION } \\
\text { 000' MT }\end{array}$ & $\begin{array}{c}\text { PDY } \\
\text { MT/HA }\end{array}$ \\
\hline UTTAR PRADESH & 262.18 & 4300.98 & 16.4 \\
\hline ANDRA PRADESH & 304.11 & 2737.01 & 9.0 \\
\hline KARNATAKA & 180.53 & 1755.58 & 9.7 \\
\hline TELANGANA & 190.88 & 1717.88 & 9.0 \\
\hline BIHAR & 149.00 & 1367.57 & 9.2 \\
\hline
\end{tabular}




\begin{tabular}{|c|c|c|c|}
\hline MAHARASHTRA & 485.00 & 1212.50 & 2.5 \\
\hline GUJRAT & 142.69 & 1125.50 & 7.9 \\
\hline TAMIL NADU & 161.58 & 785.50 & 4.9 \\
\hline ODISHA & 197.52 & 751.02 & 3.8 \\
\hline JHARKHAND & 51.33 & 517.92 & 10.1 \\
\hline KERALA & 74.44 & 441.03 & 5.9 \\
\hline WEST BENGAL & 93.50 & 430.71 & 4.6 \\
\hline OTHERS & 223.23 & 1288.04 & 5.8 \\
\hline
\end{tabular}

Sources: All India 2013-14 (Final Estimated), Department of Agriculture and Co-operation

\section{REVIEW OF LITERATURE}

The objective of SCM is to maximize competitiveness and profitability for whole supply chain, including the endcustomer at the same time. The market structure can also be defined as characteristics of the organization of a market, which seem to strategically influence the nature of competition and pricing behavior within the market Bain (1968). The marketing of fruits and vegetables is associated with a unique set of conditions which makes the task difficult and highly risky. Firstly, the nature of the produce handled itself, because of high perishability it is difficult to create time and space utilities. The second factor in marketing of fruits and vegetables is the prevailing imperfect competition i.e. there are only few traders in the business. These two factors have a lot of influence on the current marketing system of other agriculture commodities Subrahmanyam and Mruthyunjaya (1978). Product characteristics have their effect on the facilities necessary to market farm products. Bulkiness requires large storage capacities. Perishable products require speedy handling and perhaps special refrigeration also stated that functional approach to study marketing is to break up the whole marketing process into specialized activities performed in accomplishing the marketing process. The approach helps to evaluate marketing costs for similar marketing middlemen and/or different commodities and costs and benefits of marketing functions Kohls and Uhl (1985). The small holders though make a sizeable contribution to high value food production (fruits and vegetables), their access to market is constrained by scale. Their marketable surplus is small while local markets for high value commodities are thin and sale in distant urban markets raises transportation and marketing costs. Existing supply chains are long and are dominated by a number of intermediaries like assemblers, wholesalers, sub-wholesalers, commission agents and retailers. The farm gate prices for vegetables and fruits range between 20-30 per cent of the eventual retail prices in India. In developed countries such as U.S.A., U.K. and Japan, the farm gate prices for such products range between 40-55 per cent of retail prices Jain (2004). Inadequate market systems cause high food losses in developing countries. To minimize losses, the commodities produced by farmers need to reach the consumers in an efficient way the wholesale, supermarket and retail facilities providing suitable storage and sales conditions for food products. To prevent the above said losses the marketing cooperatives should be able to reduce food losses by increasing the efficiency of these activities. Although the development of wholesale and retail markets should preferably be done by the private sector, local governments and marketing cooperatives can be instrumental in establishing and improving market facilities Kader (2005).

\section{SIGNIFICANCE}

At present the unorganized retailers are linked with farmers through wholesalers or commission agents. Sometimes there would be more than one commission agent and wholesaler for the same produce to reach the retailer. The commission agents and wholesalers redundant supply chain practices make unorganized further inefficient. In horticulture produce studies shows wastages close to $25 \%$ in unorganized retailing. The wastage is far less almost 16-19\% with organized retailers compared to unorganized retailers. This proves the importance and necessity of Supply chain. Bidar district consists of five taluk and in each taluk different types of horticultural crops are under cultivation. Crops like Mango, Papaya, Banana, Fig, grapes, Pomegranate, Cashew lime etc., are being cultivated 
extensively and large quantities of these are being sent directly to Hyderabad and Mumbai markets. There is an imperative need to create marketing infrastructure for overall development of horticulture, small, segregated farmers for fair share in consumer's price for the producer in the district.

\section{OBJECTIVES}

The objective of the study is to know the existing the system, structure, marketing channels, intermediaries involved in the marketing of fruits, constraints in the marketing of fruits in Bidar district.

\section{RESEARCH METHEDOLOGY:}

The supply chain study of mangoes in Bidar district was aimed to make appraisal about the existing supply chain and problem faced by various intermediaries.

The study covers the marketing of mangoes from supply chain perspective and the study is based on, primary and secondary data collection. The primary data has been collected from the different intermediates involved in the supply chain of mangoes: producers, PHC, commission agents, wholesalers and retailers.

The secondary data has been collected from horticulture dept officials and marketing officials, national horticulture website, articles and journals.

\section{RESULTS AND DISCUSSIONS:}

\section{THE SYSTEM, STRUCTURE AND MARKETING CHANNELS OF MANGO}

At the farm level the government under national horticulture mission is providing the samplings, information, technical assistance and subsidies on drip irrigation to the farmers. Bidar has witness a good progress in horticulture cropping and the net sown area has increased. There are many APMC regulated fruit markets in Karnataka but the one is absent in Bidar, The body has initiated to provide the market space for fruit and vegetables on Secundrabad road where the market has been constructed but the area is not that enough to be suitable for fruit market, the shops have been constructed suitable for the vegetable market. Upon interaction with the commission agents and wholesalers the problem with these is the shop allotted is less and the area is not suitable for the fruits as they require large areas for storage. There are no cold storage facilities by government in Bidar, although one is proposed in Humnabad taluk but not at implemented. Private market establishment will help the farmer as well as consumer, only when proper post harvest facilities are available and transparency in pricing and quality (proper grading) are introduced and the private market takes responsibility of helping the farmer in areas like productivity improvement, orchard management, and provides post harvest facilities and transportation system. This will only happen if private or farmer association owned farmers markets are established near producing areas.

As mentioned the problem of the whole of the India for horticulture is the un-organized marketing and aggregating the problem with absence of post harvest facilities. In Bidar there is no organized retailing of the fruits, there is involvement of commission agents, wholesalers sometimes more than once.

Whole marketing channels and supply chain structure has been studied and been analyzed the complexity of the chain has been shown in the Figure-1.

\section{INTERMEDIARIES INVOLVED:}

\section{FARMERS:}

A farmer (also called an agriculturer) is a person engaged in agriculture, raising living organisms for food or raw materials. The term usually applies to people who do some combination of raising field crops, orchards, vineyards, poultry, or other livestock. A farmer might own the farmed land or might work as a labourer on land owned by 
others, but in advanced economies, a farmer is usually a farm owner, while employees of the farm are known as farm workers, or farmhands. However, in the not so distant past a farmer was a person who promotes or improves the growth of (a plant, crop, etc.) by labor and attention, land or crops or raises animals (as livestock or fish).

\section{POST-HARVEST CONTRACTOR:}

Evaluates the orchard during the initial stage of fruiting and payment is done to the farmer on per kg basis. Cost of activities such as harvesting, packing and transportation at the farm gate are borne by the contractor. Some small and marginal farmers sell their produce to contractors who visit them when the orchard is ready for the first harvest and contract with the farmers for the duration of the season. Here again farmers bear the weather risk

\section{SMALL RETAIL BUSINESSMEN:}

Including small retailers and roadside vendors also purchase their requirements directly from the growers, once the regular contractor harvests the quantity contracted to him. In this case the price is fixed by the grower depending upon the quantity purchased and the market price or contractor's price as the basis and the growers get about 10-15\% higher price for their produce.

\section{COMMISSION AGENT:}

Facilitates trade between the contractor and the wholesaler for which they charge 6-10\% commission from the contractor. The commission agents also do sorting, grading sell the produce directly to the retailers in the local market.

\section{WHOLESALER:}

$\mathrm{He}$ is responsible for distribution of produce to various retailers. Second level of sorting/grading has also been observed at the secondary/terminal markets. Accordingly, the produce is sold to retailers based on specific grades.

\section{Retailer:}

Retail is the process of selling consumer goods and/or services to customers through multiple channels of distribution to earn a profit. Demand is created through diverse target markets and promotional tactics, satisfying consumers' wants and needs through a lean supply chain. Retailing includes subordinated services, such as delivery. The term "retailer" is also applied where a service provider services the needs of a large number of individuals, such as for the public. Shops may be on residential streets, streets with few or no houses, or in a shopping mall. Shopping streets may be for pedestrians only. Sometimes a shopping street has a partial or full roof to protect customers from precipitation.

\section{MARKETING CHANNELS:}

Marketing channels are routes through which agricultural products move from producers to consumers. The length of the channel varies from commodity to commodity, depending on the quantity to be moved, the form of consumer demand and degree of regional specialization in production

The common marketing channels engaged in the marketing of mangoes in the Bidar district are

SC-1: Producer - Retailer - Consumer.

SC-2: Producer - PHC - Retailer - Consumer.

SC-3: Producer - Wholesaler - Retailer - Consumer.

SC-4: Producer - PHC - CA - Retailer - Consumer.

SC-5: Producer - PHC - Wholesaler - Retailer - Consumer. 
FIG-1: Existing supply chain of mango in Bidar.

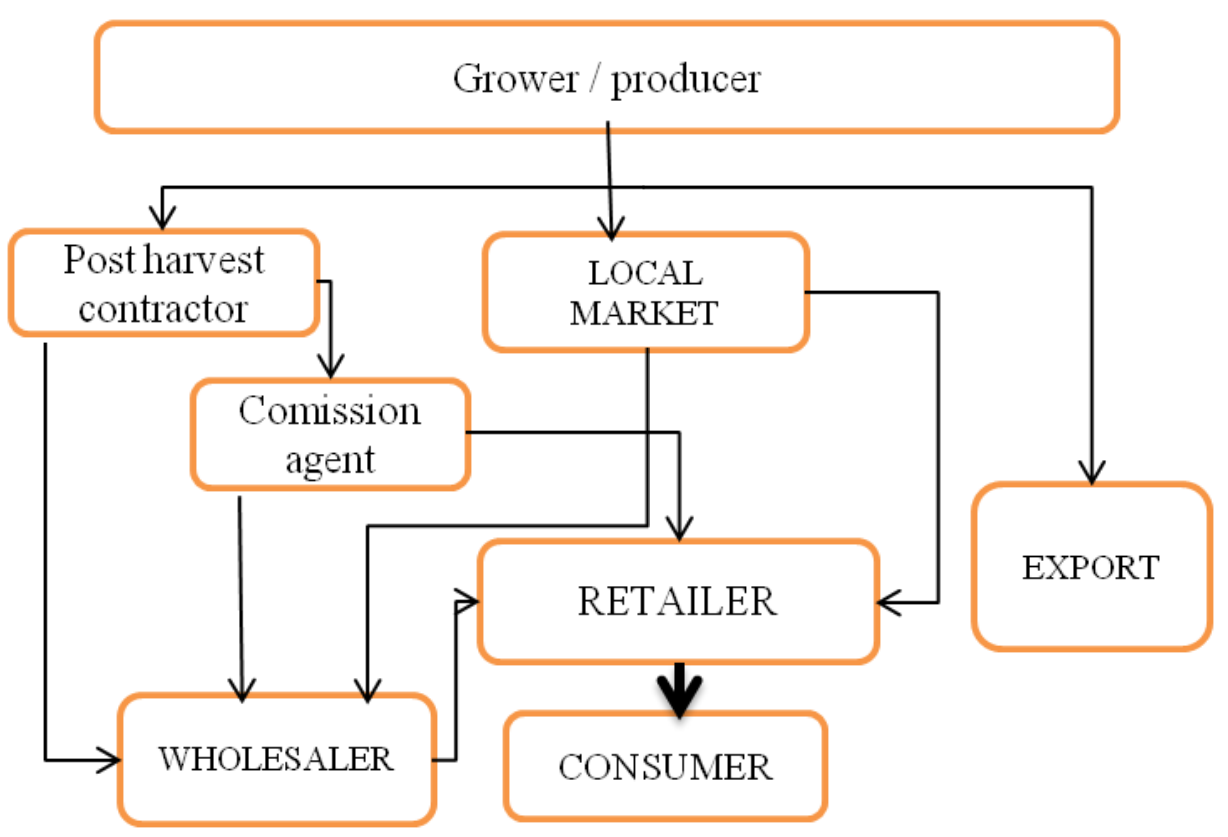

Sources: Authors own representation of the existing supply chains in Bidar, Karnataka, India

As described earlier there are various intermediaries involved in the marketing chain of mangoes in Bidar district. They are, Producers, pre-harvest contractors, post-harvest contractors, small retail businessmen, commission agents, wholesalers and retailers. The volume harvested each time is less than a ton or depend on the size of the farm. Farmers find it difficult to transport mango to collection centers of corporate buyers since the quantity is less and are thus forced to sell at general market, where price is fixed by agents/wholesalers and farmers may not get remunerative price. Most of the farmers lease orchards to the contractors at the time of flowering or fruit setting. The price received by the farmer largely depends on the stage of the orchard at which the contract takes place.

\section{DISCUSSIONS}

The government is providing many kind of institutional support for the farmers but still a lot is need to be done for transfer of technical knowhow for increasing the productivity and quality of the produce. Cold chain facility is required in the district so that producers can preserve the produce at reasonable cost. The volume harvested each time is less than a ton or depend on the size of the farm. Farmers find it difficult to transport mango to collection centers of corporate buyers since the quantity harvested is less and are thus forced to sell at general market, where price is fixed by agents/wholesalers and farmers may not get remunerative price. Most of the farmers lease orchards to the contractors at the time of flowering or fruit setting. The price received by the farmer largely depends on the stage of the orchard at which the contract takes place, here whether risk is shared by the producer, the contractors also disrespect the contact at the time of harvesting if there are problems due to whether and the producers are left with the produce which is sold at the low prices in the market. Due to involvement of intermediaries there is price escalation because of the losses in transport, margins on intermediaries and producers bear the low share in 
consumer price. To solve the problem of the involvement of the intermediaries and price escalation, Co-operatives should be formed in the district by aggregating the small farmers and transaction cost can be reduced and farmers can realize better prices for their produce, if the produce is aggregated at one place corporate retail chains can be involved in the buying and farmers can realize the better price. Organizing the retail market like Raitha Santhe started in Karnataka help to reduce the cost of intermediaries by directly selling the produce to the retailer.

\section{CONCLUSION}

The most important issue of mango/ fruit marketing in Bidar is the presence of unorganized retailing and involvement of large number of intermediaries, these leads to the escalation of prices due to increase in the margins with increase in various intermediaries augmented with the physical losses and transport and less producers share in consumer price.

At the production side the farmers should be provided with the assistance in samplings, irrigation, most important is the storage with cold chain facilities.

To increase the producers share in consumes price there is a requirement of direct selling of produce in the market organized by APMC like Raitha Santhe, The problem of involvement of the intermediaries and escalation in prices of commodities and physical losses can be sorted if the farmers co-operatives are formed which is absent in the district, there is a urgent need to establish the co-operatives for both fruits and vegetables in the district and cold chain facilities.

\section{REFERENCES:}

[1] All India 2013-14 (Final Estimated), Department of Agriculture and Co-operation.

[2] Bain, J. S., (1968). Industrial Organization. 2nd Edition, John Wiley and Sons, New York. 258p.

[3] Biswas, B.C. and Lalitkumar (2011). "Revolution in Mango Production - Success Stories of Some Farmers" Fertilizer Marketing News, March 2011. Pp. 1-23.

[4] CENTAD (2007), "Agribusiness in India: Some Facts and Emerging Issues", Agricultural Economics Research Review, Vol. 20, (Conference Issue), 2007.

[5] Horticulture handbook-2014.

[6] Jain, R.K., (2004), Agricultural Marketing Situation in India: Problems \& Prospects.

[7] Kader, A. A. (2005). Increasing food availability by reducing postharvest losses of fresh produce (2169-2176) in V International Postharvest Symposium, 682.

[8] Kohls, R, L. and J.N. Uhl. (1985). Marketing of Agricultural Product. Fifth Edition. McMillan Publishing Company, New York, USA 624p.

[9] Murthy,D.S.,Gajanana,T.M.,Sudha. and Dakshinamoorthy,V.(2007). Marketing Losses and Their Impact on Marketing Margins: A Case Study of Banana in Karnataka. Agricultural Economics Research Review, 20 (1), pp. 47-60.

[10] National horticulture board.

[11] Singh, K, and T.M.Gajanana, (2007), "Co-operative Marketing of Fruits and Vegetables in India", Concept Publishing House, New Delhi.

[12] Subrahmanyam, K.V., and Mruthyunjaya (1978), Marketing of Fruits and Vegetables around Bangalore: Problems and Prospects, Indian Journal of Marketing, 9(1), Pp 9 - 17.

[13] Usha.T, Subhash.C,(2012). Impact of Emerging Marketing Channels in Agricultural Marketing - Benefits to ProducerSeller and Marketing Costs and Margins of Agricultural Commodities in Haryana Agricultural Economics Research Centre University of Delhi. 